Disclosure of Interest: J. Braun Grant/research support from: AbbVie (Abbott), Amgen, BMS, Boehringer, Celgene, Celltrion, Centocor, Chugai, EBEWE Pharma, Medac, MSD (Schering-Plough), Mundipharma, Novartis, Pfizer (Wyeth), Roche, Sanofi-Aventis, UCB, Consultant for: AbbVie (Abbott), Amgen, BMS, Boehringer, Celgene, Celltrion, Centocor, Chugai, EBEWE Pharma, Medac, MSD (Schering-Plough), Mundipharma, Novartis, Pfizer (Wyeth), Roche, Sanofi-Aventis, UCB, Speakers bureau: AbbVie (Abbott), Amgen, BMS, Boehringer, Celgene, Celltrion, Centocor, Chugai, EBEWE Pharma, Medac, MSD (Schering-Plough), Mundipharma, Novartis, Pfizer (Wyeth), Roche, Sanofi-Aventis, UCB, J. Sieper Grant/research support from: AbbVie Inc., Pfizer Inc., and Merck, Consultant for: AbbVie Inc., Pfizer Inc., Merck, UCB, and Novartis, Speakers bureau: AbbVie Inc., Pfier Inc., Merck, and UCB, R. Landewé Grant/research support from: Abbott, Amgen, Centocor, Novartis, Pfizer, Roche, ScheringPlough, UCB, Wyeth, Consultant for: Abbott/AbbVie, Ablynx, Amgen, AstraZeneca, Bristol-Myers Squibb, Centocor, GlaxoSmithKline, Novartis, Merck, Pfizer, Roche, Schering-Plough, UCB, Wyeth, Speakers bureau: Abbott, Amgen, Bristol-Myers Squibb, Centocor, Merck, Pfizer, Roche, Schering-Plough, UCB, Wyeth, X. Baraliakos Grant/research support from: AbbVie, BMS, Celgene, Chugai, Merck, Novartis, Pfizer, UCB, Werfen, Consultant for: AbbVie, BMS, Celgene, Chugai, Merck, Novartis, Pfizer, UCB, Werfen, Speakers bureau: AbbVie, BMS, Celgene, Chugai, Merck, Novartis, Pfizer, UCB, Werfen, C. Miceli-Richard Grant/ research support from: Abbott/AbbVie, Bristol-Myers Squibb, Novartis, Merck, Pfizer, Wyeth, Consultant for: Pfizer, Roche, UCB, Wyeth, Merck, Speakers bureau: Abbott, Bristol-Myers Squibb, Merck, Pfizer, Roche, Schering-Plough, Wyeth, E. Quebe-Fehling Employee of: Novartis, B. Porter Shareholder of: Novartis Pharmaceutical Corporation, Employee of: Novartis Pharmaceutical Corporation, K. Gandhi Shareholder of: Novartis Pharmaceutical Corporation, Employee of: Novartis Pharmaceutical Corporation, D. van der Heijde Consultant for: AbbVie, Amgen, Astellas, AstraZeneca, BMS, Boehringer Ingelheim, Celgene, Daiichi, Eli-Lilly, Galapagos, Gilead, Glaxo-Smith-Kline, Janssen, Merck, Novartis, Pfizer, Regeneron, Roche, Sanofi, Takeda, UCB DOI: 10.1136/annrheumdis-2018-eular.2052

\section{SAT0289 LONG-TERM EFFECTS OF TNF-ALPHA INHIBITORS ON BONE MINERAL DENSITY AND THE INCIDENCE OF VERTEBRAL FRACTURES IN PATIENTS WITH ANKYLOSING SPONDYLITIS}

K. Beek ${ }^{1}$, M. van der Weijden ${ }^{1}$, T. Rusman ${ }^{1}$, W. Lems ${ }^{1}$, C. van Denderen ${ }^{2}$, M. Nurmohamed ${ }^{1}$, I. van der Horst-Bruinsma ${ }^{1} .{ }^{1}$ Rheumatology, Amsterdam Rheumatology immunology Centre/VUmc and Reade; ${ }^{2}$ Rheumatology, Amsterdam Rheumatology immunology Centre/Reade, Amsterdam, Netherlands

Background: Ankylosing Spondylitis (AS) is not only characterised by pathological bone formation leading to ankylosis, but also by bone loss which may lead to vertebral fractures (VFx). TNF-alpha inhibitors (TNFi) have proven to be effective in blocking the inflammatory process. A few studies also showed an increase of Bone Mineral Density (BMD) in AS patients treated with TNFi ${ }^{1-3}$, however, the incidence of VFx after two years of treatment was increased. ${ }^{3-4}$

Objectives: To evaluate the long-term effect of TNFi on BMD and the incidence of VFx in patients with AS.

Methods: Consecutive TNFi naive AS patients (who fulfilled the Modified New York criteria) were included. Patients were recruited from the VUmc and Reade and were treated with TNFi for 4 years. BMD at hip and lumbar spine (LS) were measured at baseline and after 4 years. T-scores were categorised as 'normal BMD', 'osteopenia' and 'osteoporosis', based on the WHO osteoporosis criteria. ${ }^{5}$ The incidence of VFx was determined by two observers using the Genant method. ${ }^{6}$

Results: In total, 107 AS patients with complete datasets (68.2\% male) were included. The mean age was 42.6 years and the disease duration (time since diagnosis) was 11.0 years. The use of steroids or osteoporosis profylaxis varied respectively between $0.9 \%$ and $2.8 \%$. At baseline $40.1 \%$ of the patients had a decreased BMD of the hip and $40.2 \%$ of the spine, of whom 27 patients $(26 \%)$ had both a decreased hip BMD as well as a decreased lumbar BMD. The BMD of spine and hip improved after 4 years of TNFi treatment (table 1). In 13 patients $(12.1 \%), 14 \mathrm{VFx}$ were observed both at baseline and after 4 years of TNFi-treatment, $26 \mathrm{VFx}$ were observed in 21 patients.

After 4 years, 4 out of 21 patients with $\geq 1 \mathrm{VFx}$ had a decreased BMD at hip and lumbar spine whereas the other 17 patients had a normal BMD. The majority of VFx was localised in the mid or lower thoracic spine.

Table $1 \mathrm{BMD}$ measurement in spine and hip of 107 AS patients treated with TNFi.

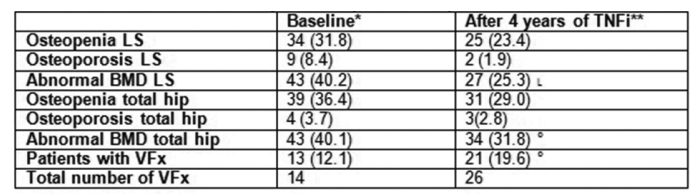

*1 patient with spondylodesis; 4 patients with a total hip replacemen

* 2 patients with spondylodesis; 5 patients with a total hip replacement

LS: lumbar spine, Abnormal BMD = osteopenia and/or osteoporosis according to WHO guideline ${ }^{6}$ Vertebral fractures (VFx)are presented in number of patients with a VFx and the actual prevalence of VFx. Outcomes are presented in $\mathbf{n}(\%)$

$p<0.05$, L $p<0.001$

Conclusions: The percentage of relatively young AS patients with a decreased BMD at baseline of the hip and lumbar spine was high (40\%). After 4 years of TNFi-treatment, the BMD of the lumbar spine improved in $14.9 \%$ of the patients and of the hip in $8.3 \%$ of the patients. At baseline, $12 \%$ of the patients had vertebral fractures which increased to $21 \%$ after 4 years of treatment. A normal population of 1984 individuals above 50 years showed a prevalence of $8.9 \%$ osteoporotic spinal fractures. ${ }^{7}$ Probably, the start of treatment with TNFi at an earlier stage of the disease might prevent the onset of fractures in AS.

\section{REFERENCES:}

[1] Visvanathan S, et al. Ann Rheum Dis 2009.

[2] Arends S, et al. Arthritis Res Ther 2012.

[3] van der Weijden, et al. J Reumatol 2016.

[4] Maas F, et al. ClinExpRheumatol 2016.

[5] Kanis JA, et al. J Bone MinerRes 1994.

[6] Genant HK, et al. J Bone MinerRes 1993.

[7] Lotters FJ, et al. Calcif Tissue Int 2016.

Disclosure of Interest: None declared

DOI: 10.1136/annrheumdis-2018-eular.4769

\section{SAT0290 CANADIAN ADALIMUMAB POST-MARKETING OBSERVATIONAL EPIDEMIOLOGICAL STUDY ASSESSING THE EFFECTIVENESS OF ADALIMUMAB VS. NON-BIOLOGIC DMARDS IN ANKYLOSING SPONDYLITIS (COMPLETE-AS): 12-MONTH EFFECTIVENESS DATA}

L. Bessette ${ }^{1}$, M. Khraishi ${ }^{2}$, A. Chow ${ }^{3}$, V. Pavlova ${ }^{4}$, S. Silverberg ${ }^{5}$, J. Stewart ${ }^{6}$, V. Remple ${ }^{7}$. 'Laval University, Centre Hospitalier de l'Université Laval, Quebec; ${ }^{2}$ Memorial University of Newfoundland, St. John's; ${ }^{3}$ University of Toronto, Toronto; ${ }^{4}$ McMaster University, Hamilton; ${ }^{5}$ Etobicoke General Hospital, Toronto; ${ }^{6}$ University of British Columbia, Penticton; ${ }^{7}$ AbbVie Corporation, Montreal, Canada

Background: COMPLETE-AS is an ongoing Canadian observational study of anti-TNF $\alpha$ naïve adults with active AS per the judgment of the treating physician, who require change in current AS treatment to either ${ }^{1}$ a subsequent NSAID or non-biologic disease modifying antirheumatic drug (nbDMARD group), $\mathrm{or}^{2}$ to adalimumab (ADA group).

Objectives: The aim of this analysis was to describe and compare the baseline demographic and disease parameters of patients in the nbDMARD and ADA groups and to compare the 12 month effectiveness of the two treatment methods. Methods: In the current analysis patients enrolled between July/2011 - Jun/2016 were included. Outcome measures analysed were extra articular manifestations (EAM 1: IBD, psoriasis, uveitis, enthesitis; EAM 2: IBD, uveitis, enthesitis), disease activity (BASDAI), functional status (BASFI), and quality of life (QoL; SF-12). Between-group differences in baseline parameters were assessed with the Chisquare test for categorical variables and the independent samples t-test for continuous variables. Baseline-adjusted changes in BASDAI and BASFI over time were compared between the two groups using linear mixed models.

Results: A total of 609 patients ( $n b D M A R D n=177, A D A n=432$ ) were included in the current analysis. No significant differences in baseline demographics were observed between the two groups. However, at baseline, patients initiating ADA were more likely to be unemployed ( $38 \%$ ADA vs. $27.1 \%$ nbDMARD, $p=0.009$ ), had higher mean BASDAI (6.4 vs. $5.0 ; p<0.001)$ and BASFI (5.5 vs. $3.7 ; p<0.001)$ scores, and worse QoL (SF-12 PCS: 24.4 vs. 24.7, $\mathrm{p}=0.002$ ) at baseline. The baseline prevalence of EAMs was comparable between the two groups (EAM 1 $34.7 \%$ vs. $31.6 \%, p=0.454$; EAM 2: $25.9 \%$ vs. $22.6 \%, p=0.381$ ). However, IBD was more common among patients initiating ADA treatment ( $9 \%$ vs. $4.5 \%$, $\mathrm{p}=0.062$ )

After 12 months of treatment the prevalence of EAMs decreased significantly in the ADA group (EAM 1: $p=0.004$; EAM 2: $p=0.033$ ) but not in the nbDMARD group. After adjusting for baseline values, patients treated with ADA had numerically lower BASDAI score (least square means - LSM: 3.7 vs. 4.3, $p=0.171$ ) significantly lower BASFI score (2.9 vs. $3.6, p=0.031)$ scores, and comparable SF12- 